\title{
Benefits of Cooperation between Buyers and Providers: a study in the field of information and communications technology
}

\author{
Beneficios da Cooperação entre Compradores e Fornecedores: um estudo no setor \\ de tecnologia de informação e comunicação
}

Beneficios de la Cooperación entre los Compradores y Proveedores: un estudio en el sector de tecnología de la información y comunicación

\section{Eliane Pereira Zamith Brito ${ }^{1}$ Gabriel Mariotto ${ }^{2}$}

Received on May 24, 2012 / Approved on June 14, 2013

Responsible Editor: João Maurício Gama Boaventura, Dr.

Evaluation Process: Double Blind Review

\begin{abstract}
This study examined the relationships between manufacturers and their distributors and retailers in the Information Technology sector. The characteristics of these relationships were identified, particularly cooperation between buyers and suppliers, and its impact on the relationship performance. Four cooperative behaviors represented the idea of cooperation. Efficiency and effectiveness were used as a performance evaluation of the relationship. Interviews with company managers were the main source of data. This research identified a significant level of cooperation within relationships, and exchange of information, joint problem-solving and flexibility were the most visible behaviors. The positive effect of cooperation in partner
\end{abstract}

satisfaction concerning the relationship was observed, leading managers to the decision to buy and to a positive experience as to the relationship. The study also showed that effectiveness feeds back the process.

Keywords: Cooperation. Buyer-supplier relationship. Effectiveness. IT industrial sector.

\section{RESUMO}

Este estudo analisou os relacionamentos entre fabricantes e seus distribuidores e revendas no setor de Tecnologia da Informação. Buscou-se identificar as características desses relacionamentos, particularmente a existência de cooperação entre compradores e fornecedores e o impacto da cooperação no desempenho

1. Doctor in Administration by the University of Manchester, UK. Professor at the Getúlio Vargas Foundation ( FGV-EAESP). [eliane.brito@fgv.br]

2. Master in Business Administration by FGV-EAESP. [gabrielmariotto@gmail.com]

Authors' address: Rua Itapeva, 474 - Bela Vista, São Paulo - SP - CEP 01332-000 - Brazil 
do relacionamento. A cooperação foi avaliada a partir de comportamentos cooperativos. Eficiência e eficácia foram usadas como avaliação de desempenho do relacionamento. Entrevistas com gestores das empresas do setor foram a fonte principal de dados do estudo. A pesquisa identificou um nível significativo de cooperação nos relacionamentos, sendo mais salientes os comportamentos do tipo troca de informação, resolução conjunta de problemas e flexibilidade. Foi constatado o efeito positivo da cooperação na satisfação dos parceiros com o relacionamento, o que leva à decisão de compra do gestor e a uma experiência positiva com o relacionamento. Evidenciou-se também que a eficácia retroalimenta o processo.

Palavras-chave: Cooperação. Relacionamento no canal de distribuição. Eficácia. TIC.

\section{RESUMEN}

Este estudio examinó las relaciones entre los fabricantes y sus distribuidores, y sus revendedores en el sector de las Tecnologías de la Información. Se identificaron las características de estas relaciones, en particular la cooperación entre compradores y proveedores, y su impacto en el desempeño de la relación. Cuatro comportamientos cooperativos representan la idea de la cooperación. La eficiencia y la eficacia se utilizaron como una evaluación de desempeño de la relación. Las entrevistas con los directivos de estas empresas han sido la principal fuente de datos. La investigación identificó un importante nivel de cooperación en las relaciones y el intercambio de información. La resolución conjunta de los problemas y la flexibilidad son los comportamientos más destacados. Se observó un efecto positivo de la cooperación en la satisfacción de los socios con la relación, lo que conduce a la decisión de compra de un gerente y una experiencia positiva con la relación. El estudio también mostró que el nivel de eficacia de la relación retroalimenta el proceso.

Palabras clave: Cooperación. Canales de distribución. Eficacia.

\section{INTRODUCTION}

Smith, Carroll and Ashford (1995), in the introduction of a special issue of the Academy of Management Journal that dealt with the theme of "cooperation", state that, although cooperation can bring various results, one of the most sought after is the coordination of agents, which presumably leads to increased performance. In this sense, understanding how cooperation can contribute to better performance is the goal of studies in the field of management, specifically as to the relationship between buyers and suppliers.

Terpend et al. (2008) describe research on the relationship between buyers and suppliers published in 1986 and 2005, systematically analyzing articles published on the subject in four USA magazines with an excellent reputation (JSCM, JOM, AMJ, SMJ). The authors' first conclusion is that the number of articles published increased over time; the amount over the past five years (2001-2005) was four times greater than that during the first five years (1986-1991). They identified increased interest about new mechanisms for creating value within relationships and through relationships between suppliers and buyers, and a gradual decline in the percentage of studies addressing buyers' activities. There was a significant increase in the number of articles about the mutual efforts of the parties, which can be interpreted as cooperation, and represented about $50 \%$ of the articles. The exchange of information predominates as the most frequently studied mutual effort; few other types are evaluated in a small number of studies. In addition, alternative measures to operating performance in evaluating creation of values by relationships have become more frequent and present in a greater number of studies. Amongst these alternative measures are the ones that evaluate the value generated by integration and cooperation between the parties.

The authors' research indicates there is a gap in the studies that deal with cooperation, because there are several possible mutual efforts or cooperative behaviors (HEIDE; MINER, 1992; JOHNSTON et al., 2004; MAHAMA, 2006; MESQUITA; BRUSCH, 2008; WILSON, 
NIELSON, 2001) and these studies have basically explored only one of them - information exchange. More recent studies have dealt sometimes with other types of cooperative behavior, but do not necessarily associate it with performance. Thus, this study aims to verify the presence of cooperative behaviors within relationships between buyers and suppliers in the Information and Communications Technology (ICT) sector, and to explore the effects of these behaviors on relationship performance. The focus of research is on the relationship between manufacturers and distributors of equipment and their retailers, and considers that cooperation plays a central role in coordinating the distribution of products and services (ANDERSON; NARUS, 1990; CANNON; PERREAULT, 1999; MORGAN; HUNT, 1994).

The focus on a specific sector occurred because previous research points to the relativity of the effects of cooperation in this context (DYER; HATCH, 2006; TURNBULL; OLIVER; WILKINSON, 1992).

The IT sector in Brazil has grown significantly. The Brazilian Association of Information Technology Distributors (ABRADISTI, 2010) estimates that, between 2010 and 2011, the sector grew 7.6\%, reaching US\$ 12.7 billion in revenues (BALD, 2011). The association also points to the fact that the number of retailers of IT products in Brazil grew from 29.500 to 31.000 ; and $23 \%$ of that corresponding to dealerships begun in 2010 and 2011 - that is, there is a significant renovation of intermediaries in the distribution channel in the industry. In addition, new customers were included in the market and there is a tendency to migrate the value of products to software and services connected to them. These features have led managers to experience a highly dynamic and extremely uncertain phase, which facilitates the adoption of cooperative strategies in order to reduce uncertainty (DAS; JOSHI, 2007; LEVINTHAL; FICHMAN, 1988; LÓPEZGAMERO; MOLINA-AZORIN; CLAVERCORTÉS, 2011; OLIVER, 1990).
Possible impacts of cooperation on the performance of relationships between manufacturers and their distributors (buyers) include those associated with economic effectiveness, because of the reduction of transaction and coordination costs and of those associated with effectiveness, such as the satisfaction of economic agents with relationship (LIGHT; HAGELAAR; OMTA, 2003; MOHR; SPEKMAN, 1994) and strategic motivation to serve customers better than competitors and the consequent increase in customers' willingness to pay (KIM, K., 1999).

The present study collected qualitative data from manufacturers, distributors and retailers of hardware and software. The analysis shows that the four cooperative behaviors coexist; restriction to the use of power is less evident. Furthermore, the presence of cooperative behavior between buyers and sellers leads to the development and effectiveness of the relationship. There is also an indication that effectiveness feeds back the development process of the relationship itself. The study reinforced the difficulty of assessing the efficiency of vertical governance structures composed of different organizations.

The paper is divided into four sections - Theoretical References, Research Methods, Results and Analysis and Conclusions. Each of these sections is divided into subsections for better organization of the text.

\section{THEORETICAL REFERENCES}

This section presents the theoretical basis of the study and is divided into three parts. The first presents the theoretical perspective the study is based on. Next, we discuss the concept of cooperation and its operation; finally, we present the concept of performance and how it was treated in this study.

\section{I Relational perspective}

The importance of situations in which there are frequent and ongoing transactions 
between buyers and suppliers has been gradually recognized in business literature. Thus, other social sciences, as well as economics, began to be used in the description of relationships between companies. From Law came significant contributions, such as the concept of "relational exchanges", introduced by MacNeil (1981). These exchanges are, in general, governed by "relational norms", which can be understood as shared expectations about the behavior of the parties involved in trade (HEIDE, JOHN, 1992).

MacNeil (1981) proposes the organization of trade in a continuum which has, at one end, discreet transactions, in which there is little communication and content and the identity of the parties is ignored (DWYER; SCHURR; OH, 1987); and, at the other, relational exchanges, where there is a relational context and single transactions are unimportant when compared to relationship as a whole (KAUFMANN, STERN, 1988).

Studies have been carried out attempting to analyze situations involving relational exchanges (ANDERSON; NARUS, 1990; DWYER; SCHURR; OH, 1987; DYER, 1997; DYER; HATCH, 2006; DYER; SINGH, 1998; HEIDE; JOHN, 1992; KAUFMANN; STERN, 1988; LAVIE, 2006; MESQUITA; ANAND; BRUSH, 2008; MORGAN; HUNT, 1994; PALMATIER et al., 2006; SCHOENHERR; SWINK, 2012), with emphasis on efforts to improve mutual relationships. Despite studies on the topic, Schoenherr and Swink (2012) argue that the theory of integration in relationships is still underdeveloped, lacking new efforts in conceptualizing and consolidating research results. Accordingly, this study takes the concept of cooperation and explores the potential effects of cooperation.

\subsection{Cooperation}

Cooperation is a topic of interest in several disciplines such as economics, sociology, anthropology, psychology, political science, organizational studies and strategy (SMITH, CARROLL, ASHFORD, 1995). The literature on cooperation is therefore multidisciplinary.
Generically, "cooperation [...] refers to situations in which separate parts work together to achieve mutual goals and individual goals with reciprocity over time" (ANDERSON and NARUS, 1990, p. 45), which would not be economically achieved individually (MALONI; BENTON, 2000; PALMATIER et al., 2006). Thus, one party commits to the other when the former realizes that it will benefit from the knowledge, skills or resources the latter presents (JONSSON; ZINELDIN, 2003).

Some studies use agreements such as alliances or joint ventures, as a proxy for cooperation (OUM et al., 2004; PARKHE, 1993). Others understand cooperation as a unidimensional concept (CRAVENS; SHIPP; CRAVENS, 1993; GEYSKENS; STEENKAMP; KUMAR, 2006; MORGAN; HUNT, 1994; PRAHINSKI; BENTON, 2004). Some define cooperation as cooperative behaviors, which can manifest in different ways, implying a multidimensional operationalization of the concept. The number of dimensions of the concept or cooperative behaviors varies between studies; the most frequent dimension is information exchange, as pointed out by Terpend et al. (2008). The study by Heide and Miner (1992), which is one of the most cited in the buyer-supplier relationship literature, operationalizes the cooperation concept as four cooperative behaviors - flexibility to adjust actions, exchange of information, joint problem solving and moderation or restriction on the use of power. In their study, cooperative behaviors are dependent variables of the theoretical model, that is, they analyze variables that can lead to cooperative behavior. Among the variables analyzed by the authors are the frequency of transactions, the longevity of the relationship, the ambiguity of the performance and the difficulty of replacing the partner.

The four cooperative behaviors of Heide and Miner (1992) can be interpreted as follows: flexibility in negotiations overcomes the fact that it is impossible, or very costly, to establish complete contracts to resolve unforeseen issues in recurrent interactions of a distribution channel. Joint problem-solving works in a similar way. The 
exchange of information benefits the operation, since it minimizes uncertainty regarding the frequency and volume of transactions between parties. Finally, as to power, if the most powerful participants in the channel make unreserved use of it, seeking to impose conditions and solutions for their own benefit, cooperation between them is impaired; however, if power is used to manage, structure and organize the channel, conditions are favorable to the existence of cooperative behavior among participants. These dimensions proposed by Heide and Miner (1992) are of fundamental importance to this study, since they use exactly these behaviors to assess the presence of cooperation between links in the distribution channel.

Mahama (2006), who was inspired by Heide and Miner (1992), uses the four cooperative behaviors, but unlike the original reference, cooperation is a mediating variable in the theoretical model of the author. Similarly, Wilson and Nielson (2001) operationalize four cooperative behaviors that comply with what was proposed Heide and Miner (1992), but they use cooperation as the independent variable and not related to performance measures. Johnston et al. (2004), on the other hand, used three behaviors - shared planning, flexibility and joint responsibility for the execution of tasks, therefore, only one of these coincides with the proposed Heide and Miner. The study linked the three behaviors with performance and satisfaction with the relationship, but only flexibility had statistically significant results. Mesquita and Brush (2008) also used three behaviors - cooperative information exchange, flexibility and solidarity. The latter evaluates the reciprocity and fairness in relationships. The authors use behaviors as predictors of efficiency of trading and production, with the moderating variables asset specificity and complexity of exchanges. They are based on the Theory of Transaction Costs.

The Heide and Miner (1992) proposal seems to be the most complete and served as a reference for most studies dealing with cooperation and cooperative behavior, and therefore chosen for the research reported here.
Thus, this study operationalizes cooperation as used in the proposed Heide and Miner.

\subsection{Performance}

Authors claim that the construct performance and how to measure it in the context of a domestic firm still lack a consensus, even if it the main dependent variable in studies on strategy (CARTON; HOFER, 2006; COMBS; CROOK; SHOOK, 2005). When it comes to the performance of a system as interorganizational vertical structures or the relationships between buyers and suppliers, there is even less defined.

Besides the difficulty in defining performance, there is still the difficulty of establishing cause and effect relationships between buyers and suppliers. Wilkinson (2001), based on March (1996) comments that in less tightly coordinated systems, such as networks, it is very difficult or even impossible to track specific outcome or impact to the actions that produced it, because the effects of these actions are complex.

Dyer and Singh (1998) attribute the gains to relational four aspects: transaction specific investments required for the activities of organizations involved in the transaction; joint learning derived from the joint action, creation of new products, services or technologies differentiated, and lower transaction costs than competitors, because of effective governance.

To enable the objectives of this research sought to simplify and limit the scope of the discussion about performance. The discussion here turns to the analysis of two concepts linked to performance, which appear in the literature on the subject and the background outline two complementary objective ways of addressing performance, they are: efficiency and effectiveness.

Mouzas (2006) presents a comparison between efficiency and effectiveness in business networks. The author states that efficiency is related to minimizing costs and increasing operating margins and effectiveness would be the ability of a company or set of companies generate sustainable earnings growth with the networks that surround it. He says that managers 
should seek both efficiency and effectiveness. On the one hand, the exclusive pursuit of efficiency can become a trap, because the company will ignore the creation and development of new sources of value for sustainable growth. On the other, not concern for costs and margins may compromise the profitability, preventing the business. Therefore, regardless of the various designs on performance in the literature, the research adopts the concepts of efficiency and effectiveness, as defined by Mouzas (2006) and a perceptual perspective, or tries to capture how the manager realizes the efficacy and interviewee efficiency.

\section{RESEARCH METHODS}

The research was exploratory in nature and is based on qualitative data collected through semistructured interviews. Were collected perceptions of respondents about the relationship between manufacturers and their dealers, emphasizing the occurrence of cooperative behaviors and their impact on the performance of the distribution.

From the list of companies in the annual Melhores \& Maiores (2010) have identified 32 companies in the "Digital Factory". Each company was analyzed for its specific activity. Were maintained in the list of potential companies to research the equipment manufacturers or software companies, therefore, excluded those whose business is consulting or manufacturing supplies or parts. To this list were added technology companies listed in the annual Most Admired Companies in Brazil's Charter Capital (BUSINESS ..., 2009) and for failing financial information in Brazil are not on the list of the biggest and best. Thus, we obtained a list of 31 companies that were contacted and asked to participate in the study. Of these, six agreed to participate and gave an interview. Manufacturers were asked to nominate companies that took care of the distribution of their products. Of the eight companies indicated, we three agreed to participate in the research. These distributors have indicated that the brand manufacturer Lenovo was a special case in the industry, the speed at which grew its global presence and the fact that he started the distribution of products in the Brazilian market represents an atypical case and potentially rich to understand the phenomenon of interest. The company was contacted and agreed to participate.

Each interview lasted between 45 minutes and an hour. At each interview, the transcript was made of its content. As the descriptions of the facts by the respondents, i.e., their perceptions are of interest to the analysis, only the words were transcribed, i.e., the emphases and other sounds made by respondents were despised, as recommended by Gibbs (2007).

To support the analysis of the interviews used field notes taken by the interviewer (GIBBS, 2007). Secondary data collected about each company also supported the analysis of the facts described by the interviewee.

Gibbs (2007) recommends that the interview guide is adjusted throughout the process of data collection so that it can better capture the phenomenon of interest, as it learns from the collection process. Thus, a roadmap has been formulated from the literature review and used in the first two interviews with the intention to assess whether it was appropriate to verify the presence of cooperative behaviors in relationships between buyers and suppliers in the industry and to explore the effects of these behaviors in performance relationship. This phase also served to be understood that the differences in the language of public research in relation to the research focus, and set the script and anticipated challenges that could harm the search. From the initial interviews it was found that respondents associated cooperation trust, leadership, information exchange, capacity building, planning and distribution cooperative, open, clear communication and problem solving in partnership. Thus, the dimensions of potential cooperation in the literature (HEIDE; MINER, 1992), two were explicitly mentioned in the responses: information sharing and joint problem solving. The training of the sales force - training, planning and distribution cooperative members 
were also cited, and therefore just as entering additional issue in the script used in the interviews, to assist in identifying the presence of cooperative behavior in the light of the characteristics of the sector. Preliminary interviews also indicated the appropriateness of using the efficiency and effectiveness for assessing the performance of the channel and how to define these concepts, describes as one of the interviewees: "The way I understand it is this: there are channels that are complete, that do everything right, is efficient, but the guy does not get the result, not enough in numbers. And we saw a lot of that in the matter of sales channel and service channel. And efficiency is one that will meet the goals and in what matter. (E1)." Chart 1 summarizes the structure of the interviews.

\begin{tabular}{|l|l|}
\hline Credentials \\
\hline Company and interviewee position & To identify cases \\
\hline $\begin{array}{l}\text { Experience managing relationships } \\
\text { in channels }\end{array}$ & To identify cases \\
\hline Context & Contextualization \\
\hline Structure of distribution & Contextualization \\
\hline Profile of retailers & To assess the formality of the relationship, formal x relational contracts \\
\hline Relationship characteristics & To assess the proximity, the form of interaction and the exchange of information \\
\hline Contract & To assess the building of trust; flexibility and exchange of information \\
\hline Frequency & To assess the transformation of transactions into routines; long-term guidance \\
\hline Personal bond & To assess the existence of specific mutual investments \\
\hline Duration of relationship & To assess the existence of specific mutual investments \\
\hline Joint action & To assess the existence of specific mutual investments \\
\hline Distribution & To assess the cooperative behavior “flexibility" \\
\hline Training & To assess the cooperative behavior "moderation in the f use of power" \\
\hline Cooperation & To assess the cooperative behavior "joint problem-solving" \\
\hline Flexibility & To assess the cooperative behavior "exchange of information" \\
\hline Use of power & $\begin{array}{l}\text { To assess perceived performance of the distribution, ways of measuring performance } \\
\text { and explore how cooperation affects this performance }\end{array}$ \\
\hline Problem-solving &
\end{tabular}

CHART 1 - Schematic script used in interviews

Source: the authors.

So that there was similarity in the data collected in the first two companies and others, please access to the two new companies consulted in the initial data collection. Thus, Microsoft and IBM had two interviews each, and in total 12 interviews were made.

The criteria used for the selection of respondents was as follows: to have significant managerial experience of at least two years in relationships with distributors and retailers, and be professional acting in the Brazilian market. Chart 2 shows the relationship between companies and the profile of the respective respondents. 


\begin{tabular}{|l|l|l|}
\hline Company & Interviewee's position & Experience managing channels \\
\hline IBM & Channel director & Over 10 years \\
\hline Microsoft & Partner Account Manager & 5 years \\
\hline Lenovo & Marketing Manager & Over 10 years in the position \\
\hline HP & Channel manager & Over 10 years in various positions within the company \\
\hline Dell & Channel manager & 2 years \\
\hline Itautec & Channel manager & 2 years with channels and over 10 years in the sector \\
\hline IBM & Channel diretor & 15 years \\
\hline Microsoft & Channel manager & 10 years \\
\hline SAP & Sales manager & 5 years \\
\hline Avaya & Channel manager & 10 years \\
\hline Ingram Micro & President & 15 years \\
\hline Network 1 & Channel manager & 10 years working with channels in distributors \\
\hline
\end{tabular}

CHART 2 - Companies and profile of interviewees who participated in research.

Source: the authors.

Data analysis occurred in stages. At first, each individual interview was analyzed and its contents, encoded by two people. This procedure was used to control the reliability of the analysis. Agreement rates were not calculated, but the differences were discussed until there was agreement on the coding, as suggested by Saldaña (2009). With that sought to give greater reliability to the process. After coding was done work for understanding how the codes could be interpreted in conjunction and alternative interpretations. Following the interviews were analyzed in a comparative manner in order to find patterns of answers to theoretical questions raised by research. Then, we performed a joint analysis of the ideas of respondents for each point of the interview, tying, thus the content of the interviews to survey questions. Excerpts that most contributed to illustrate the results were selected as research evidence. Each section is associated with respondents highlighted through codes (E1, E2, [...], E12). The results are presented in the sequence.

\section{RESULTS AND ANALYSIS}

This section is organized into four subsections, the first of which describes the structure of the industry surveyed. The second part describes the relationship between buyer and supplier in this industry. The cooperation between buyer and supplier is explored in the third part, and the last describes the effectiveness and efficiency measures adopted to evaluate the performance of the relationship and how they relate to cooperation.

\section{I Structure of distribution in the IT sector}

The latest estimates of revenue from IBGE (2010) show that income level in the manufacturing of items related to IT grew by approximately $16 \%$ between 2009 and 2010 and the wholesale and retail trade increased in the same period $15 \%$ and $23 \%$, respectively. The IT market in Brazil is composed of hardware (48\% of total revenues), software (17\%) and services (35\%) (VALIM, 2010). Although the hardware segment is clearly still the greatest, he has been decreasing in recent years, falling $10 \%$ in 2009 , whereas the segments of software and services grew (VALIM, 2010). This reflects the trend of adopting standardized hardware, as pointed out by research institutions such as Computerworld (2008), forcing companies to seek to add value through software and especially services. Given this segmentation, this study sought to delimit the scope of analysis to the segments primarily hardware and software, since the distribution of services by specific features that significantly differentiate the products. 
The main types of intermediaries who distribute this sector are distributors, systems integrators for corporate sales, resellers and retailers. This latter type is generally used as an alternative to the distributor-reseller channel and serves mainly the individual segment. There are two basic types of resale, the selling products just as they are offered by the manufacturer and those that deliver products or services to such offer.

The dealers, in most cases, lack of planning and structuring, and with increased competition and consolidation in the market, they risk not survive or be acquired by another company. "The profile of most of these companies is similar: the owner is an engineer who saw your small business take off because in recent decades the use of technology has increased exponentially" (OHL, 2006). These companies are not necessarily denominated retailers by respondents, and that, in their speech, always referring to it used here the term "resale" to facilitate the understanding of the reader.

Manufacturing companies surveyed, all of them showed to have a well-defined distribution structure with operational strategy that reflects a general segmentation of the enduser market. There are small changes in relation to such cleavage, but, in general, companies share the market similarly, since these segments are defined on the basis of objective characteristics of the market. Ways to meet these different market segments change from manufacturer to manufacturer, but also many similarities. Thus, it was possible to build, from the description of respondents a generic framework that represents the distribution in the IT sector in Brazil. This structure has been improved over the process of interviews, as the contribution of each interview, and the result is shown in Figure 1. This representation does not reflect the structure adopted by a particular company, but what is more usual in the sector. You can see the different ways used to distribute the products, but each with the potential to differentiate their offering from that of competitors. The lack of differentiation effective supply can lead to conflict between the parties and, accordingly, the cooperative behaviors may have a fundamental role to reduce the possibility of conflict.
It is worth noting that the figure follows the vertical design traditional distribution structures and were represented mainly transactional connections between members. If relationships were represented in a complete, that is, not only the relations that generate transaction of goods or services - communication flows, partnership programs, among other things, the structure would be much more complex.

Still on the profile of retailers, respondents indicated there is much variability among them, as one might expect. For example, the question arises concerning the internal structure and organization of these resellers: "Regarding the organization, there is variability. Some dealers are organized, have a vision of the future, business, evolution, a way of acting, and others that are the business owner "(E5), one respondent pointed out. The main differences between dealers were identified:

- size - large companies are minority and most are small businesses, using the criteria of turnover or number of employees - " $[\ldots]$ companies that are half a dozen people [...] and others that are even good sized [... ] that have 50, 80 employees" (E5). But most are "he, his son and his wife. Are small businesses with the minimum of strategic planning, marketing nothing. The guy closes the store in the afternoon because he has to serve in loco. He sells his lunch to pay for his dinner" (E6).

- added value - "has a diverse fauna. I have since only channels that sell PCs, to valueadded channels, services or products that add themselves to our offering, taking it to the end customers "(E12).

- structure - among retailers that have some structure and planning (minority) and those that have no structure and planning (mostly) - "a serious problem is the lack of strategic planning [...] almost never asked what is that they want to be when you grow up, where they want to get where they are targeting "[...] (E10)" [...] is the 'pastel': folder and telephone. The guy with his briefcase and his telefoninho, is the dealer simpler "(E8). 


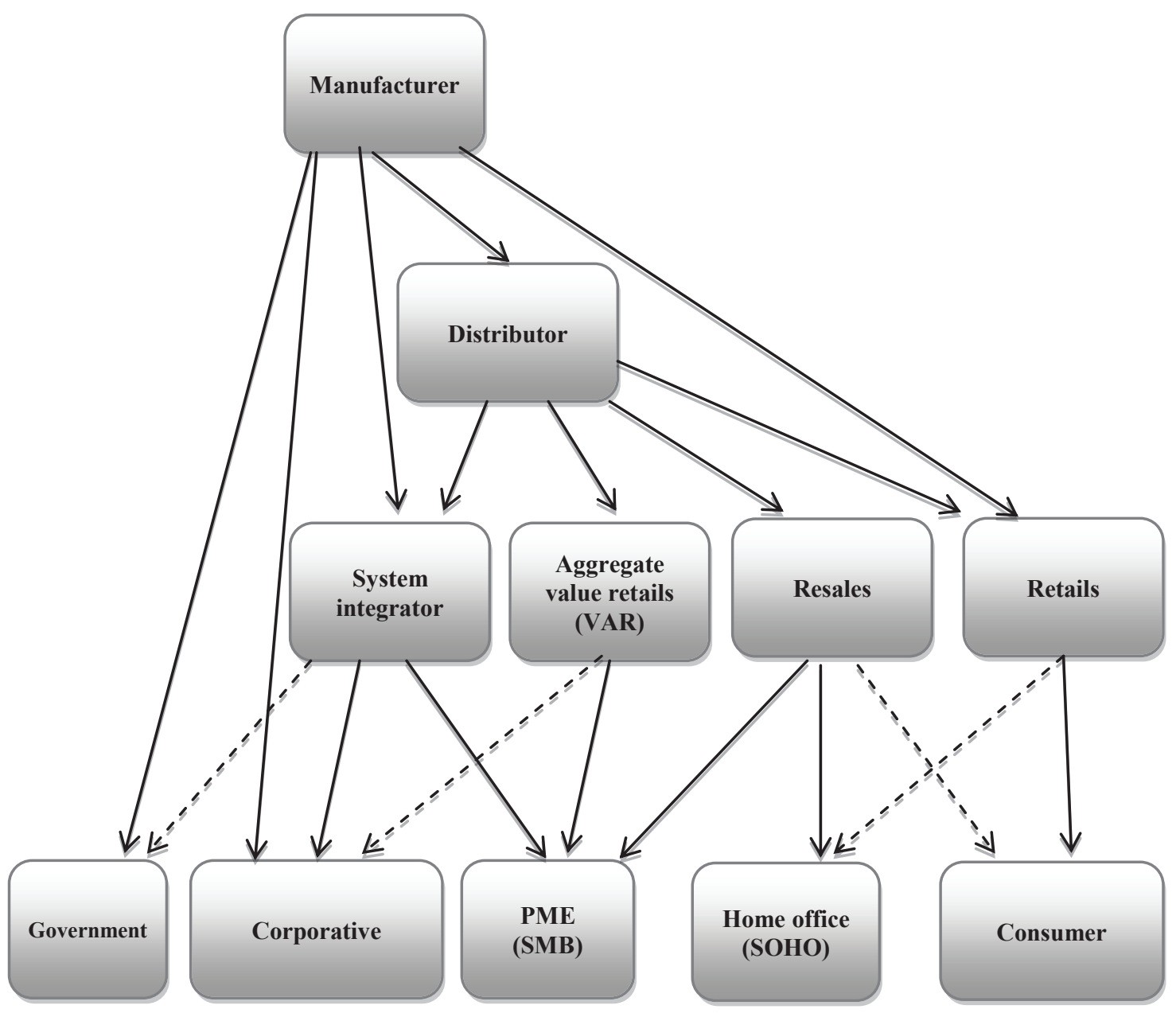

FIGURE 1 - Generic structure of distribution within the ICT sector.

Source: the authors, based on research data.

These three variables - size, structure and value - are clearly correlated. According to one interviewee, the "degree of structure depends on the size of the partner, as it needs money left over to make planning and marketing activities" (E3). Another said: "Distributors and retailers that add value have a good structure, planning etc" (E4), and a third reported that "not necessarily the retailers that add value are larger, structured, but as a general rule, we say yes" (E8).

\subsection{The relationship between agents}

There was a significant variation in the degree of formality in the relationship between manufacturers and their dealers. At one extreme, one of the manufacturers claimed to have formal contracts with all retailers, due to the fact that they are the largest and most qualified dealers who buy directly from the manufacturer and not through distributor. At the opposite extreme, another manufacturer said his company has no contract with reseller or business relationship, as they relate to the distributor.

On the other hand, a respondent states that there is always a formal agreement with the manufacturer and described the nature of the contract:

For each manufacturer you distribute, you must have to have a distribution agreement, usually an international contract. And that contract you will have multiple policies from payment, warranty policy products, most wanted items, sales goals, [...] Finally, the agreement is very complete and complex. (E9) 
A figure was as important in the relationship with retailers is the manager responsible for direct and frequent contact with retailers (boundary spanner). He is the main interlocutor of information exchange between firms in the relationship, as your contact with dealers by phone or email is daily face visits with weekly or biweekly. "Trust is often you have on your channel, it has to be there forever, you have to build a relationship. You do not build a relationship once a month, or by calling the Customer from time to time. (E10) "This contact is recognized as essential and determining the effectiveness of relationships between companies, especially the constant exchange of information and confidant and building confidence, reinforcing the ideas Perrone, and Zaheer McEvely (2003) and Heide and Miner (1992) on the construction of the frequency relationship. Note, however, that this agent may pose some risks to the organizations involved, because the personal connection may eventually become stronger than the bond organization. But this risk can be mitigated by promoting turnover of managers is, as one interviewee explains: "have to encourage a turnover, but you begin to create relationships permissive. Because at the end of the day, who pays the wages of the seller is the channel, is selling what he does (E4) ".

Being this close and frequent contact with buyers and potential to offer flexibility to the relationship, it can promote cooperative behavior in the relationship and, more than that, it can be a catalyst for cooperation in the relationship. The strengthening of the personal ties between individuals in the relationship between separate organizations is important and predominantly beneficial but should not be ignored its possible side effects, such as loss of efficiency for the accommodation and even the loss of the employee and, consequently, the relationship with the other company. Perrone, and Zaheer McEvely (2003) reinforce the importance of contact for the relationship, but highlight the importance of seniority contact, company culture, the longevity of the relationship between organizations and routines for the positive effects emerge. So, for cooperation to emerge and endure, it takes more than the relationship between the agents of contact.

The duration of the relationship with the manufacturers or distributors retailers, it became clear that it varies for resale, but the answers are not allowed to identify as clearly as possible that duration influences the nature of the relationship. On the one hand it was suggested that the time is needed to build the relationship, then there is a positive correlation between time and quality of the relationship: "all channel manager has a learning curve, it has an intimacy curve" (E10). On the other hand, it was also suggested that a shorter-term orientation is not necessarily bad for the conduct of business, "no channels that focus on the customer and not the vendor, and then make arrangements for temporary partnership with the supplier, which is good one hand the business spin fast, but otherwise invest little in relation '(E8). However, the longevity of the relationship has been considered a consequence rather than a determinant nature of the relationship. "Time is a consequence. The maintenance of the relationship depends on trust, performance, work aligned. This generates the channel time. "(E4) can assume there is a feedback variable, as revealed Golicic and Autry (2010). Heide and Miner (1992) construct its argument whereas the longevity of the frequency relationship and interactions increase the likelihood of favorable behavior to the relationship, which can lead to higher disposition to maintain the relationship.

It was observed that joint is a common practice in the relationship between manufacturers and their distributors or retailers. Interviewees said to have included in its program of relationships with retailers and scope of work of the sales manager (contact), action planning in conjunction with each resale. The results of this work plan that gets names as co-business plan. Several respondents also used the expression "four hands" to emphasize the custom to realize this plan together. The plan addresses issues such as "sales, training, distribution, processes, services, installation and support." An important detail to be emphasized is that distributors seek to align their planning with manufacturers and retailers 
channel, often targeting the service. Kim, K. K. et al. (2010) showed that the alignment of goals is a relevant factor for cooperation between companies in the telecommunications industry and planning is an effective way to align goals.

It is evident that the attempts of manufacturers approach to its retailers are, in particular, the most relevant. This movement can generate a positive spiral and a consequent improvement in performance, which leads to the strengthening of the relationship and a new cycle of the spiral, as evidenced Golicic and Autry (2010). Confidence and elapsed time appear as relevant to building the relationship and alignment of actions between parties, as evidenced Wilson and Nielson (2001).

\section{$4 \cdot 3$ Cooperation between buyers and suppliers}

As explained in the theoretical framework, the cooperative behaviors are adopted as proxy cooperation, and the four cooperative behaviors mentioned by Heide and Miner (1992), and explained earlier in this paper, we analyzed, with findings presented in sequence.

The issue of flexibility is associated with the existence of formal contracts in the relationship between the companies previously mentioned. That's because, of course, the more rigid and detailed the contract, there is less scope for use of flexibility as a management tool. But still, as one respondent explained, the main function of the formal contract is to govern every transaction and ongoing business relationships between companies, but to provide legal protection for more delicate cases. In this sense, the use of the term "umbrella contract" by another respondent is illustrative:

You have an umbrella contract $[. .$. which defines what the rules of the game, you depend on what, what are the roles and responsibilities. But day by day [...] occurring things like: 'I'll have to ask for in this business, for us to win the competition, you gain very little or not winning anything. But then I'll compensate somehow. 'Then it generates a compensation relationship itself that occurs. (E1)
The majority of respondents indicated a reasonable level of flexibility in the relationship between the companies, but within established principles, as can be seen in the sections below.

I direct my staff very caring Registration opportunities primarily in the sense of not. If you must say no, say now. All this does not mean that I do not meet a resale to appear, proposing a business that is an opportunity that is not registered in our system. (E5)

Yes, there is a degree of flexibility. However, significant changes compared to the contract can be updated with all partners or be created some addendums. (E7)

I have flexibility mechanisms, but upon request and approval. If not combined before, is more difficult. Taking the ethical side, which we do not ever give up if it is a business aspect, we will discuss trade and if it makes sense and is not hurting our supply chain, we do. (E12)

When asked about how to deal with power differences between the parties, the majority of respondents said there was no significant difference in power between companies and their retailers. Only one said that "arguably, the greater the power of our company (manufacturer)" (E6) and another partially admitted: "Of course, economically speaking, our company is greater than their buyers, but this is not something that changes something in the way of the game "(E5). This same interviewee explained well in microeconomic terms why this balance of power, "is a matter of the market. You do not have a dealer who holds $40 \%, 50 \%$ of the market and I did not stop him this supply side. Fragmentation is broad, both in supply and in demand. (E5) “, thereby reducing the power of the parties. It is worth pointing out, however, that respondent represented a company that worked with relatively few dealers, predominantly retailers that add value, that is, had a greater selectivity in their distribution. In fact, according to the literature, a factor that could cause an imbalance of power would be the relative dependence 
or interdependence asymmetry between the parties (ANDERSON AND NARUS, 1990; KIM, KK ET AL., 2010; KUMAR; SCHEER; STEENKAMP, 1995; REVE; STERN, 1979) and a way to measure this would be dependent on the alternative options available for each piece (KIM, KK et al., 2010) and switching costs (switching costs) to replace the partner (AYMARD; BRITO, 2009; HEIDE, JOHN, 1988). Thus, if the manufacturer has many retailers making the distribution, it is less dependent on each separately, and the side of resale, if it is a multibrand retail and / or add value to the product, that depends less on specific manufacturer, as reported by one respondent: "Depending on the situation, has a balance of power in the business relationship. And this is bound up with where you are depending on your channel. So, why always tries to avoid at all costs an exclusive relationship channel (E1)."

It is observed that the pattern of responses of respondents reinforces this argument, because the only interviewee who claimed to be the undisputed largest power company with its retailers is precisely that which has a distribution channel structure with greater intensity, ie, lower selectivity with a large number of small retailers sell their product almost exclusively. The others just referring predominantly to larger retailers that add value to the process and with whom they have a close relationship. There may be an imbalance of power in the case of the relationship between manufacturers and dealers, but it depends on the type of resale, mainly from its size, with which the manufacturer is dealing with, and this intensifies the greater is the intensity distribution of the manufacturer.

What matters most for this item analysis of the research, however, is not whether there is an imbalance of power and under what conditions, but as the parties deal with this imbalance, if it exists, considering that this aspect is one of the dimensions cooperation between companies. The critical point here is that few responses were collected in this sense, since most of the respondents said there was no such imbalance. Anyway, between the responses collected was some evidence that there is a significant moderation in the use of power for the maintenance of the relationship and the partner as well. One respondent, referring to a situation of partner opportunism, in which your company could have used his greater power of coercive manner, said the standard procedure is a conversation in a friendly tone (E6).

When asked about the search for joint problem solving, responded with a surprising similarity. The word "transparency" was consistently emphasized.

You always have to have to manage, and above all, provide transparency. Warn the guys about the problem. Does not invent any story, tell what happened. And the sooner, the better. (E5)

Very transparent and clear communication, always, and as quickly as possible, so that this does not impact the life of the man or the business man. (E6)

The best way to deal with crises is undoubtedly transparency. (E4)

The basic word we have here is transparency. It is always so honest dealing with the channel, assuming the problem, be honest in what is happening and take action together. (E7)

Transparency was consistently emphasized in the interviews, which at least shows the importance of this issue and the business concern to maintain a clear policy against partners. Mahama (2006) argues that transparency is that the behaviors become more visible, which helps in maintaining desired behaviors and stability of the relationship. Thus, the answers to this question also served to demonstrate the efforts of manufacturers and distributors gain the confidence of its partners, as one dimension of trust is often used in the literature is the confidence in the honesty of the partner (Anderson and Narus, 1990; Dwyer, Schurr, OH, 1987). And being one of the major trust antecedents of cooperation, the answers just pointing also to a search of cooperative behavior, albeit indirectly. 
There was also, however, answers that addressed the critical issue, which was to point the way to solving the problems. The last statement of the above list touches precisely this central point and cites the attitude of "take steps together." Other statements that pointed to this action "joint", "partnership", to solve problems were:

In general, it is going to try to understand and solve the problem together with customers. The best is that people manifest, so we can know of the problem, instead of silently losing the relationship by not knowing. (E11)

Acting in partnership is essential. You have to live with your partner, show that you are interested in understanding the pain of the face, and to the extent that problems arise, the best way to treat is to sit together and resolve. (E10)

Although the focus of the issue of problem solving has made a slight detour to take issue transparently responsibility for the problem, it can be stated that there was support the existence of a cooperative attitude to jointly solve the problems that arise in the relationship and its derivatives.

The exchange of information, such as extent of cooperation between companies, received particular attention in the answers of respondents. One of them pointed out the difference in the type of information that each party has, thus creating a potential for complementarity that information exchange can accomplish: "Exchange of information is essential. Because, what I say is, 'the manufacturer's on that side, it has the product vision, he has research'. "(E10)

On the other hand, the market view that intermediaries of distribution channel can offer was mentioned by one respondent:

Since the distributor ends up having multiple manufacturers therefore multiple chains of relationships, there is a constant exchange of information between the dealer lot and manufacturers, in the following sense: if I have relationships with manufacturers that sell, for example, headset, and I have relationship with manufacturers that sell - call center PBX, hey, the two ends, of course, will have interest in mutual complementarity. So, the distributor uses this ability to promote multimarket stock sales. (E9)

It is then observed that the exchange of information actually occurs and the frequency of contact here helps to show that the exchange of information occurs not only as it is constant. Of course, the intensity and the means by which this change occurs varies with the degree of importance of the partner, as indicated by Hatch and Dyer (2006).

Chart 3 summarizes the analysis of cooperative behaviors investigated by assigning levels found in the scale data.

\begin{tabular}{|l|l|}
\hline Dimension & Data support \\
\hline Flexibility & Strong \\
\hline Restriction to the use of power & Medium \\
\hline Joint solution of problems & Strong \\
\hline Exchange of information & Strong \\
\hline
\end{tabular}

CHART 3 - Summary of analysis of cooperation dimensions

Source: the authors.

The relationship of manufacturers and distributors to retailers for a significant degree of cooperation, considering the cooperative behaviors investigated, once again, the exchange of information is a salient feature in the perception of managers, perhaps because of its objectivity and ease of being identified by be inherent in the transaction. The flexibility and joint problem solving require an effort by the parties to realize these manifestations of cooperative behaviors, considered also planning together, training and distribution cooperative actions, as a possible additional dimension of cooperation. Such actions require specific investments of the parties and can generate specific assets, strengthening the argument for the existence of cooperation between the parties, as suggested by the relational view (DYER; HATCH, 2006; DYER; SINGH, 1998; LAVIE, 2006) 
The analysis of characteristics of relationships - degree of formality, frequency and form of contact, personal bond and duration of the relationship - also indicates the existence of cooperation between the parties. The low degree of formality contractual in that relationship (MACNEIL, 1981; MOSQUE; ANAND; BRUSH, 2008), the high frequency of contacts, including presence, in cases of larger retailers (HEIDE; MINER, 1992), and importance of personal bond suggest the predominance of the use of a governance via relational norms for relationships, in particular the cooperation. The duration of the relationship, although it has supplied mixed data, points predominantly for a long-term orientation, which also favors the existence of cooperation (HEIDE; MINER, 1992; WILSON; NIELSON, 2001; LUI; NGO, 2012).

\subsection{Relationship performance}

The main difficulty with the question of how to measure the performance of the distribution channel is fairly clear that it is not measuring partner performance, resale or group of retailers, but the channel as a whole. Most respondents believed that was evaluating its buyer (or resale) specific and then the interviewer sought to use the term "performance distribution route or channel of distribution as a whole" (E3) to make it clear that it was not evaluate the performance of resale, partner or distributor, but the complete chain. Even so, it was realized that many of the measures cited by the respondents were still placed with a focus more punctual and located within an isolated member. These performance measures isolated from retailers or distributors, can even provide a rough indication of the performance of the channel, but this can not be generalized, since often the mere existence of a weak link can compromise the performance of the channel as a all or there may be greater value appropriation by a member of the channel and thus, the overall performance does not become evident.

Analyzing the answers, we note that, in general, the efficiency of the channel is more difficult to measure because it involves an analysis of the cost structure of the channel, it is a system formed by several independent firms, collecting accurate data is problematic. Measures of effectiveness, although also by complex multiorganizational nature of the channel, tend to be more viable and more pragmatic, being generally associated with an objective to be achieved. For example, achievement of sales targets, or market shares, are typically measures of effectiveness, and can be earned with precision.

Thus, in general, most respondents suggested measures linked to effectiveness. Few answers spoke on measures such as profitability, margins or costs, precisely because they are more difficult to be performed in cases of complex structures such as those analyzed. Quantitative measures were cited more sales, reach and frequency of transactions (sales and purchases). The majority of responses cited at least one of them.

It is noteworthy that were suggested also intangible aspects, more subjective in evaluating the performance of the channel. The answer below also emphasized the existence of these aspects, which eventually can be measured qualitatively.

I have information growth, gain market share it is succeeding add other products, we have meters till you drop. But it also has qualitative ... in a bad year, not necessarily a company that declines may be considered bad, when you look certification, suitable investment, the level of work and customer satisfaction with these partners. (E12)

O Another aspect that emerged was the participation in the mind (mind-share) customers, mainly in the partners that work with various brands, the manufacturer has to compete with other manufacturers attention and time that the partner dedicated to your product.

As a general rule, the respondents believe that it is possible to say how the relationship between the companies of the distribution channel impacts the performance of the channel as a whole. One respondent disagreed with the impact of the relationship on performance, but it was not a total disagreement. 
I would say the following: the relationship stricto sensu neither improves nor worsens the performance, but love does. The obligations of this relationship, for example, the training or the discussion of the relationship, yes, definitely improve performance. This mainly improves the pace of business and the frequency of purchases. (E5)

The respondent sought to separate the relational aspects of those more subjective more objective and formal, such as empowerment of people and conflict resolution, he translated by the word "obligations", but that could be understood as cooperation, based on the definition of cooperative behaviors. In his opinion, the former have no impact on the performance of the distribution channel, while the latter certainly have.

Therefore, it can be said that the respondents agree that the characteristics of the relationship between the manufacturer and its intermediates impact the channel performance. But despite these results attest to the importance of the study and the management of relationships between firms, especially between manufacturers and their intermediaries in the IT industry, they alone are only part of the research question raised. The central point of the question, namely, is to understand how this impact occurs. Thus, analyzing the study data, there is primarily a reference to the direct impact of the characteristics of the relationship satisfaction, and in that case it is understood that it is the satisfaction with the relationship itself. At the same time, was cited influence these relational characteristics also in investment decision on developing the relationship. And the answers suggest, though only implicitly, that this development also generates greater relationship satisfaction.

Thus, the impact of the relationship on performance measures channel more quantifiable as sales volume, frequency, capillary, were also pointed out, effects on indirect measures, such as satisfaction and its influence on the purchase decision. Besides the satisfaction with the relationship itself, has also mentioned the "shopping experience". From the responses, Figure 2 was developed and it summarizes the findings concerning the characteristics of the relationship and the impact on channel performance and development of the relationship. Figure makes a simplified picture of the phenomenon, without considering the feedback process, especially considering relationships involving repeated transactions. Based on the data, it is possible to assume that the relationships identified in Figure have a non-recursive..

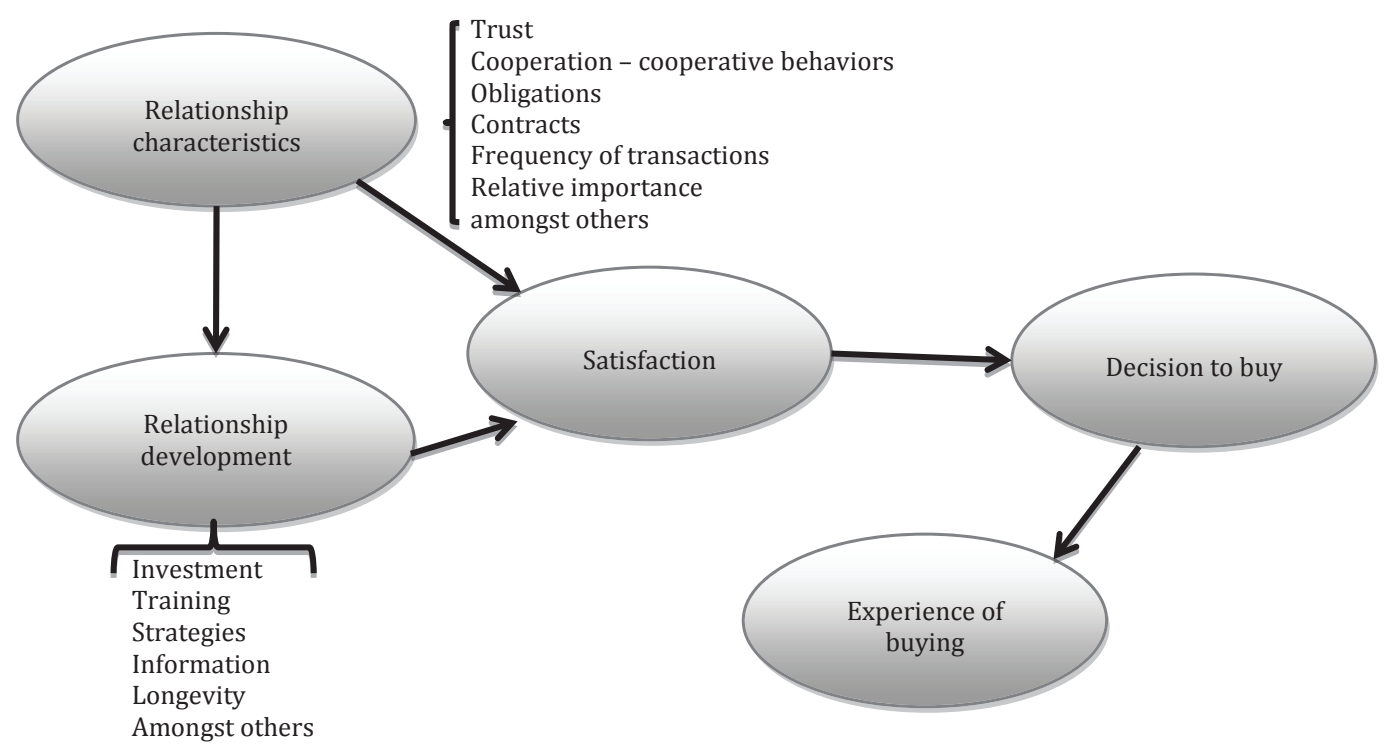

FIGURE 2 - Impact of relationship characteristics on channel performance

Source: the authors. 
Thus, the survey data support the idea that the characteristics of the relationship between buyers and suppliers in the IT industry, particularly cooperation, positive impact on channel performance, especially in the effectiveness of the channel. The analysis of the relationships between the links of the channel indicates the existence of a significant level of cooperation and, secondly, how we can see this relationship impacts the performance of the channel, particularly by the satisfaction and influence the buying decision, then it may state that the existence of cooperation impacts the performance of the channel.

\section{CONCLUSION AND LIMITATIONS}

The question about the characteristics of the relationship between the manufacturer and its intermediates revealed that there is a significant degree of cooperation between the parties. We confirmed the role of trust as a key ingredient of cooperation, as stated by Morgan and Hunt (1994) and Palmatier et al. (2006).

As to the formality of the relationship between the members of the distribution channel, it was noted that the manufacturer-distributor relationship is always mediated by a formal contract between the parties. In the comparison with the distributor resales, it was found that there is a predominance of relationship that does not involve a formal contract, and the relationship in such cases governed by relational norms. There is evidence to suggest that the size of firms is a relevant factor to define the degree of formality of the contract, but the nature of the relationship and transaction history also contribute to this definition.

It was possible to verify the existence of cooperative behaviors listed by Heide and Miner (1992), highlighting the exchange of information, flexibility and joint problem solving. There were several ways to indicate the occurrence of each type of cooperative behavior, revealing that many different kinds of efforts for the development of relationships are present in these relationships. There was, however, assessing the occurrence of each behavior on the performance of the relationship, which could be exploited in future studies.

As pointed out by Heide and Miner (1992), the longevity of the relationship helps to build the characteristics of the relationship, with the cooperation of the features. So, it is reasonable to assume that relationships older have higher level of satisfaction of the parties. It would be important to examine whether there is a breakdown or an inflection point of this curve intimacy.

The literature does not effective ways to measure the efficiency of vertical structures and the more complex they are, the harder it is to make this assessment and compare with competitors supply structures, as shown by Davies and Brito (2004). This is, for example, one of the difficulties to assess empirically the theory of transaction costs or ideas Wroe Alderson (1948) on the productivity distribution structures. This research reinforces this idea as points is not unusual sector managers surveyed use efficiency measures to their distribution channels, given the difficulty of measuring the outcomes of the structures that permeate the boundaries of a company, beginning with the use internal data of the organizations and their activities, problems of value appropriation or dispute the value created in and by the canal, also implying the complexity of apportionments derived from a contract of this. In general, performance measures focus on the individual company or measures of effectiveness are used. As a result, the impact on the performance of the relationship of the channel is estimated mainly by measures of efficacy.

Thus, this study also used measures of effectiveness of the relationship. Our data support the idea that the characteristics of the relationship between buyers and sellers have a positive impact on the effectiveness of the relationship mainly in the effective channel, measures such as sales volume, sales and frequency capillarity. This impact occurs primarily in the satisfaction of the parties involved in the relationship, which in turn directly influences the purchase decision. The satisfaction with the shopping experience 
generates a feedback process, again influencing the characteristics of the relationship and, therefore, leading to the development of relationships.

\section{REFERENCES}

ALDERSON, W. A formula for measuring productivity in distribution. Journal of Marketing, Chicago, v. 12, n. 4, p. 442-448, Apr. 1948.

ANDERSON, J. C.; NARUS, J. A. A model of distributor firm and manufacturer firm working partnerships. Journal of Marketing, Chicago, v. 54, n. 1, p. 42-58, Jan. 1990.

ASSOCIAÇÃO BRASILEIRA DOS DISTRIBUIDORES DE TECNOLOGIA DA INFORMAÇÃO - ABRADISTI. 2010. Disponível em: <http://www.abradisti.org.br/site/ pesquisas.php?id=1>. Acesso em: 01 maio 2013.

AUTRY, A. C.; GOLICIC, S. L. Evaluating buyer-supplier relationship-performance spirals: A longitudinal study. Journal of Operations Management, Amsterdam, v. 28, n. 2, p. $87-$ 100, 2010.

AYMARD, P.; BRITO, E. P. Z. Custos de mudança em serviços logísticos. Gestão $\&$ Produção, São Carlos, v. 16, n. 3, p. 466-478, jul./set. 2009.

CALVO, S. Mercado de distribuição em TI deve crescer 7,6\% em 2011. 2011. Disponível em: <http://computerworld.uol.com.br/ negocios/2011/12/07/mercado-de-distribuicaoem-ti-deve-crescer-7-6-em-2011/>. Acesso em: 01 maio 2013.

CANNON, J.; PERREAULT JR., W. D. Buyerseller relationships in business markets. Journal of Marketing Research, Chicago, v. 36, n. 4, p. 439-460, Nov. 1999.

CARTON, R. B.; HOFER, C. W. Measuring organizational performance. Cheltenham: Edward Elgar, 2006.
CLARO, D. P.; HAGELAAR, G.; OMTA, $O$. The determinants of relational governance and performance: How to manage business relationships. Industrial Marketing Management, New York, v. 32, n. 8, p. 703716, Nov. 2003.

COMBS, J. G.; CROOK, T. R.; SHOOK, C. $\mathrm{L}$. The dimension of organizational performance and its implications for strategic management research. In: KETCHEN, D.; BERGH, D. (Orgs.) Research methodology in strategy and management. San Diego: Elsevier, 2005. p. $259-286$.

COMPUTERWORLD. Gartner faz previsōes de tendências em TI para empresas até 2012. 2008. Disponível em: <http://pcworld.uol.com.br/ noticias/2008/02/19/gartner-faz-dez-previsoesde-tendencias-em-ti-para-empresas-ate-2012/>. Acesso em: 16 jan. 2010.

CRAVENS, D.; SHIPP, S.; CRAVENS, K. Analysis of co-operative interorganizational relationships, strategic alliance formation, and strategic alliance effectiveness. Journal of Strategic Marketing, London, v. 1, n. 1, p. 5570, 1993.

DAS, S. R.; JOSHI, M. P. Process innovativeness in technology services organizations: roles of differentiation strategy, operational autonomy and risk-taking propensity. Journal of Operations Management, Amsterdam, v. 25, n. 3, p. 643660, 2007.

DAVIES, G.; BRITO, E. P. Z. Price and quality competition between brands and own brands: a value systems perspective. European Journal of Marketing, Bradford, v. 38, n. 1/2, p. 30-55, 2004.

DWYER, F. R.; SCHURR, P. H.; OH, S. Developing buyer-seller relationships. Journal of Marketing, Chicago, v. 51, n. 2, p. 11-27, Apr. 1987.

DYER, J. Effective interfirm collaboration: How firms minimize transaction costs and maximize 
transaction value. Strategic Management Journal, Chichester, v. 18, n. 7, p. 535-556, 1997.

; SINGH, H. The relational view: Cooperative strategy and sources of interorganizational competitive advantage. Academy of Management Review, Briarcliff Manor, v. 23, n. 4, p. 660-679, 1998.

; HATCH, N. Relation-specific capabilities and barriers to knowledge transfers: Creating advantage through network relationships. Strategic Management Journal, Chichester, v. 27 , n. 8 , p. $701-719,2006$.

AS EMPRESAS mais admiradas no Brasil. Carta Capital, São Paulo, n. 12, nov./dez. 2009.

GEYSKENS, I.; STEEMKAMP, J. E. M.; KUMAR, N. Make, buy or ally: a transaction cost theory meta-analysis. Academy of Management Journal, New York, v. 49, n. 3, p. 519-543, 2006.

GIBBS, G. Analyzing qualitative data. London: Sage Publications, 2007

HEIDE, J. B.; JOHN, G. The role of dependence balancing in safeguarding transaction specific assets in conventional channels. Journal of Marketing, Chicago, v. 52, n. 1, p. 20-35, Jan. 1988.

; __ Do norms matter in Marketing relationships? Journal of Marketing, Chicago, v. 56, n. 2, p. 32-44, Apr. 1992.

; MINER, A. S. The shadow of the future: effects of anticipated interaction and frequency of contact on buy-seller cooperation. Academy of Management Journal, New York, v. 35, n. 2, p. 265-291, June 1992.

IBGE. Pesquisa industrial produto. 2010. Disponível em: <http://www.ibge.gov.br/home/ mapa_site/mapa_site.php\#economia>. Acesso em: 01 jan. 2013.

JONSSON, P.; ZINELDIN, M. Achieving high satisfaction in supplier dealer working relationships. Supply Chain Management: An International Journal, Bradford, v. 8, n. 3, p. 224-240, 2003.

JOHNSTON, D. et al. Effects of supplier trust on performance of cooperative supplier relationships. Journal of Operations Management, Amsterdam, v. 22, n. 1, p. 23-38, 2004.

KAUFMANN, P.; STERN, L. Relational exchange norms, perceptions of unfairness, and retained hostility in commercial litigation. Journal of Conflict Resolution, Thousand Oaks, v. 32, n. 3, p. 534-552, 1988.

KIM, K. On determinants of joint action in industrial distributor-supplier relationships: Beyond economic efficiency. International Journal of Research in Marketing, Amsterdam, v. 16, n. 3, p. 217-236, Sept. 1999.

KIM, K. K. et al. Inter-organizational cooperation in buyer-supplier relationships: Both perspectives. Journal of Business Research, New York, v. 63, n .8, p. 863-869, 2010.

KUMAR, N.; SCHEER, L. K.; STEENKAMP, $\mathrm{J}$. The effects of perceived interdependence on dealer attitudes. Journal of Marketing Research, Chicago, v. 32, n. 3, p. 348-356, Aug. 1995.

LAVIE, D. The competitive advantage of interconnected firms: An extension of the resource-based view. Academy of Management Review, Briarcliff, v. 31, n. 3, p. 638-658, 2006.

LEVINTHAL, D. A.; FICHMAN, M. Dynamics of interorganizational attachments: Auditor-client relationships. Administrative Science Quarterly, Ithaca, v. 33, n. 3, p. 345-369, Sept. 1988.

LÓPEZ-GAMERO, M. D.; MOLINA-AZORÍN, J. F.; CLAVER-CORTÉS, E. Environmental uncertainty and environmental management perception: a multiple case study. Journal of Business Research, New York, v. 64, n. 4, p. 427-435, 2011. 
LUI, S. S.; NGO, H. Drivers and outcomes of long-term orientation in cooperative relationships. British Journal of Management, Oxford, v. 23, p. 80-95, 2012.

MELHORES \& MAIORES: as 1000 maiores empresas do Brasil. Revista Exame, São Paulo, n. 971-E, jul. 2010. Edição Especial Exame.

MACNEIL, I. The new social contract: an inquiry into modern contractual relations. New Haven: Yale University Press, 1981.

MAHAMA, H. Management control systems, cooperation and performance in strategic supply relationships: A survey in the mines. Management Accounting Research, London, v. 17, p. 315-339, 2006.

MALONI. M.; BENTON, W. C. Power influences in the supply chain. Journal of Business Logistics, Oak Brook, v. 21, n. 1, p. 49-73, 2000.

MARCH, J. G. Continuity and Change in Theories of Organizational Action. Administrative Science Quarterly, Ithaca, v. 41, n. 2, p. 276-287, 1996.

MESQUITA, L.; BRUSH, T. Untangling safeguard and production coordination effects in long-term buyer-supplier relationships. Academy of Management Journal, New York, v. 51, n. 4, p. 785-807, 2008.

; ANAND, J.; BRUSH, T. Comparing the resource-based and relational views: knowledge transfer and spillover in vertical alliances. Strategic Management Journal, Chichester, v. 29, n. 9, p. 913-941, 2008.

MOHR, J.; SPEKMAN, R. Characteristics of partnership success: partnership attributes, communication behavior and conflict resolution techniques. Strategic Management Journal, Chichester, v. 15, n. 2, p. 135-152, Feb. 1994.

MORGAN, R. M.; HUNT, S. D. The commitment-trust theory of relationship marketing. Journal of Marketing, Chicago, v. 58, n. 3, p. 20-38, 1994.

MOUZAS, S. Efficiency versus effectiveness in business networks. Journal of Business Research, New York, v. 59, n.10/11, p. 1124-1132, Oct. 2006.

OHL, M. Rota para o crescimento. Info Canal, São Paulo, n. 12, maio 2006. Disponível em: <http://info.abril.com.br/canal/edicoes/12/ conteudo_135517.shtml>. Acesso em: 16 jan. 2010 .

OLIVER, C. Determinants of interorganizational relationships: integration and future directions. Academy of Management Review, Briarcliff, v. 15, n. 2, p. 241-265, 1990.

OUM, T.H. et al. The effect of horizontal alliances on firm productivity and profitability: evidence from the global airline industry. Journal of Business Research, New York, v. 57, n. 8, p. 844-853, 2004.

PALMATIER, R. W. et al. Factors influencing the effectiveness of relationship marketing: a metaanalysis. Journal of Marketing, Chicago, v. 70, n. 4, p. 136-153, 2006.

PARKHE, A. Strategic alliance structuring: A game theoretic and transaction cost examination of interfirm cooperation. Academy of Management Journal, New York, v. 36, n. 4, p.794-829, 1993.

PERRONE, V.; ZAHEER, A.; MCEVILY, B. Free to be trusted? Organizational constraints on trust in boundary spanners. Organization Science, Linthicum, v. 14, n. 4, p. 422-439, 2003.

PRAHINSKI, C.; BENTON, W.C. Supplier evaluations: communication strategies to improve supplier performance. Journal of Operations Management, Amsterdam, v. 22, n. 1, p. 39-62, 2004 .

REVE, T.; STERN, L. W. Interorganizational relations in Marketing Channels. Academy 
of Management Review, Briarcliff, v. 4, n. 3, p. 405-416, July 1979.

SALDAÑA, J. The coding manual for qualitative researchers. London: Sage Publications, 2009.

SCHOENHERR, T.; SWINK, M. Revisiting the arcs of integration: cross-validations and extensions. Journal of Operations Management, Amsterdam, v. 30, n. 1-2, p. 99-115, 2012.

SMITH, K.; CARROLL, S.; ASHFORD, S. Intra- and interorganizational cooperation: toward a research agenda. Academy of Management Journal, New York, v. 38, n. 1, p.7-23 Feb. 1995.

TERPEND, R. et al. Buyer-supplier relationships: derived value over two decades. Journal of Supply Chain Management, Malden, v. 44, n. 2, p. 28 55, 2008.
TURNBULL, P.; OLIVER, N.; WILKINSON, B. Buyer-supplier relations in the UK - automotive industry: Strategic implications of the Japanese manufacturing model. Strategic Management Journal, Chichester, v. 13, n. 2, p. 159-168, 1992.

VALIM, C. E. A. Mercado de TI terá mais peso no PIB nacional. Brasil Econômico, ano 2, n. 76, 2010.

WILKINSON, I. A history of network and channels thinking in Marketing in the 20th Century. Australasian Marketing Journal, Melbourne, v. 9, n. 2, p. 23-52, 2001.

WILSON, E.; NIELSON, C. Cooperation and continuity in strategic business relationships. Journal of Business-to-Business Marketing, Binghamton, v. 8, n. 1, p. 1-24, 2001. 